\title{
Pengaruh Pelatihan Menggosok Gigi Dengan Metode Storytelling Terhadap Kemampuan Menggosok Gigi Pada Anak Usia Prasekolah
}

\section{The Effect of Teeth Bringing Training With Storytelling Methods on the Ability of Teeth Brushing in Preschool Age Children}

\author{
Meto*, Ifana Anugraheni, Endang Mei Yunalia \\ *Program Studi Ilmu Keperawatan, Fakultas IImu Kesehatan, \\ Universitas Kadiri, Jl. Selomangleng No.1 Kediri \\ e-mail: meto85901@gmail.com
}

\begin{abstract}
ABSTRAK
Ketrampilan menggosok gigi pada anak usia prasekolah perlu dilatih agar anak memiliki ketrampilan menggosok gigi, salah satu cara yang dapat digunakan adalah menggosok gigi dengan metode bercerita. Hasil survey awal yang dilakukan menunjukkan masih rendahnya ketrampilan menggosok gigi anak prasekolah. Tujuan penelitian adalah untuk mengetahui pengaruh pelatihan menggosok gigi menggunakan metode storytelling terhadap kemampuan menggosok gigi pada anak praskolah. Penelitian Pre Eksperimen ini menggunakan rancangan One Group Pretest dan Posttest dengan jumlah sampel 70 responden yang dipilih dengan metode Purposive Sampling. Hasil uji statistik dengan menggunakan Uji Wilcoxon menunjukkan $\mathrm{p}$-value $=0,000(\mathrm{a} \leq 0,05)$, artinya ada pengaruh pelatihan menggosok gigi dengan metode story telling terhadap ketrampilan menggosok gigi pada anak usia prasekolah. Melatih anak usia prsekolah dalam menggosok gigi menggunakan metode bercerita ini sesuai untuk diterapkan pada anak usia prasekolah karena dengan metode bercerita pesan yang disampaikan lebih mudah diterima oleh anak.
\end{abstract}

Kata kunci- Pelatihan menggosok gigi, Prasekolah, Storytelling

\section{ABSTRACT}

Teeth brushing skills in preschool children need to be trained so that children have the skills to brush their teeth, one way that can be used is to brush teeth with the storytelling method. The results of the initial survey conducted indicated that the skills of brushing teeth in preschool children were still low. The research objective was to determine the effect of training on brushing teeth using the storytelling method on the ability to brush teeth in pre-school children. This pre-experimental research used the One Group Pretest and Posttest design with a sample size of 70 
respondents who were selected by the purposive sampling method. The results of statistical tests using the Wilcoxon test showed $p$-value $=0.000(a \leq 0.05)$, meaning that there was an effect of tooth brushing training using the storytelling method on brushing skills in preschool children. Training preschool-aged children in brushing their teeth using this storytelling method are suitable for preschool children because by using the method of telling messages, the messages conveyed are easier for children to accept.

Keywords: Teeth brushing training, preschool children, storytelling

\section{PENDAHULUAN}

Masalah yang biasanya terjadi pada anak usia prasekolah adalah berkaitan dengan kebersihan perorangan dan lingkungan yang salah satunya adalah menggosok gigi yang baik dan benar. Masalah kesehatan gigi dan mulut setiap tahun terus meningkat sehingga menjadi perhatian yang penting dalam pembangun di bidang kesehatan khususnya pada anak prasekolah yang rentan terhadap gangguan kesehatan gigi dan mulut sehingga terhindar dari masalah kesehatan gigi dan mulut tersebut (Warni,2010).

Prevalensi nasional masalah kesehatan gigi dan mulut pada tahun 2007 adalah 23,2\% dan tahun 2013 adalah 25,9\%, proporsi masalah gigi dan mulut berdasarkan kelompok usia prasekolahpada tahun 2007 sebanyak 28,5\% dan tahun 2013 sebanyak 39,3\%. Berdasarkan data yang didapat bahwa persentase anak prasekolah yang mempunyai keterampilan menggosok gigi yang benar hanya $15,6 \%$. Persentase tertinggi pada anak prasekolah yang mempunyai kebiasaan menggosok gigi setelah bangun tidur pagi sebesar $61,8 \%$, sedangkan kebiasaan menggosok gigi setelah makan pagi hanya $11,7 \%$ dan sebelum tidur malam $23,3 \%$. Untuk perilaku dalam menggosok gigi ditemukan sebagian besar penduduk Indonesia menggosok gigi pada saat mandi pagi maupun sore sebanyak $76,6 \%$ sedangkan perilaku menggosok gigi dengan benar yaitu setelah makan pagi dan sebelum tidur malam, untuk Indonesia ditemukan hanya 2,3\% (Riskesdas, 2013).

Masalah kesehatan gigi dan mulut pada anak prasekolah di Kalimantan Tengah pada tahun 2015 mencapai angka 43,6\% jauh lebih banyak bila dibandingkan dengan persentase pada tahun 2014 sebanyak 25,2\%. Berdasarkan data yang diperoleh, untuk masalah kesehatan gigi dan mulut pada anak usia prasekolah di Kabupaten Lamandau pada tahun 2016 mencapai angka 449 kasus yang terjadi di seluruh wilayah kerja puskesmas (Dinas Kesehatan Kabupaten Lamandau,2017). Diwilayah kerja Puskesmas Bulik, untuk masalah kesehatan gigi dan mulut pada tahun 2016 mencapai angka 200 kasus (Laporan LB 1, Puskesmas Bulik, 2016). Hasil survey awal yang dilakukan bahwa informasi kesehatan tentang menggosok gigi sudah pernah dilakukan tetapi belum dilaksanakan evaluasi dari tenaga kesehatan. 
Hasil wawancara yang dilakukan pada 70 siswa, 29 siswa mengatakan menggosok gigi pada pagi dan malam hari, 14 siswa hanya pada pagi hari saja, dan 27 siswa menggosok gigi pada saat mandi pagi saja.

Salah satu upaya untuk meningkatkan keterampilan anak prasekolah tentang menggosok gigi yang benar yaitu dengan melakukan penyuluhan kesehatan. Penyuluhan kesehatan sangat penting diberikan kepada anak usia prasekolah sehingga dapat menunjang status kesehatan anak usia prasekolah. Penyuluhan kesehatan ini disampaikan seperti proses belajar, yaitu melalui proses input (subjek keluar) kemudian proses belajar itu sendiri dan output yang merupakan hasil dari belajar (Notoatmojo, 2010). Penyuluhan kesehatan ini dapat dilakukan dengan berbagai macam metode. Salah satu metode yang dapat digunakan adalah penyuluhan kesehatan dengan memberikan pelatihan tentang menggosok gigi adalah dengan cara bercerita. Bercerita merupakan jembatan komunikasi yang efektif dalam menyampaikan pelajaran kepada anak-anak baik dirumah maupun disekolah (Hasanah, 2013). Penelitian Silver (2011) menyatakan bahwa story telling atau bercerita adalah sebuah metode yang sudah digunakan sebagai sarana pendidikan sejak ribuan tahun yang lalu. Masyarakat menggunakan metode bercerita untuk menanamkan moral dan perilaku.

\section{METODE PENELITIAN}

Jenis penelitian adalah penelitian Pre Eksperimental dengan rancangan penelitian One Group Pretest dan One Group Posttest. One Group Pretest dan One Group Posttest adalah rancangan dengan tidak menggunakan kelompok pembanding (kontrol) namun sudah dilakukan observasi pertama (Pretest) yang memungkinkan peneliti dapat menguji perubahan yang terjadi setelah adanya pengaruh pemberian penyuluhan kesehatan dengan menggunakan metode story telling pada perilaku menggosok gigi yang benar pada usia prasekolah dan data dikumpulkan adalah data sebelum dan sesudah perlakuan. Sampel penelitian ini adalah siswa TK Melati Nanga Bulik Kabupaten Lamandau sebanyak 70 siswa. Penelitian ini dilakukan dengan cara memberikan pre test (pengamatan awal) terlebih dahulu sebelum diberikan perlakuan $(\mathrm{x}$ ) setelah diberi perlakuan, kemudian dilakukan kembali post test (pengamatan terakhir) hal ini dilakukan untuk mengetahui perbedaan yang di hasilkan antara pre test dan post test. 


\section{HASIL DAN PEMBAHASAN}

\section{Ketrampilan menggosok gigi sebelum pelatihan storytelling}

Tabel 1 Distribusi frekuensi ketrampilan menggosok gigi sebelum pelatihan storytelling

\begin{tabular}{cccc}
\hline No. & Ketrampilan menggosok gigi & $\mathbf{f}$ & $\mathbf{( \% )}$ \\
\hline 1 & Baik & 14 & 20 \\
2 & Cukup & 24 & 34,3 \\
3 & Kurang & 32 & 45,7 \\
\hline & & $\mathbf{7 0}$ & $\mathbf{1 0 0}$ \\
\hline
\end{tabular}

Berdasarkan hasil observasi ketrampilan menggosok gigi sebelum responden mendapatkan story telling dapat disimpulkan bahwa hampir setengahnya ketrampilan menggosok gigi pada responden adalah kurang, yaitu sebanyak 32 responden (45,7\%). Ada beberapa faktor yang menyebabkan kurangnya ketrampilan menggosok gigi pada anak usia prasekolah, antara lain terbatasnya informasi, rendahnya kesadaran akan pentingnya menjaga kebersihan gigi dan mulut. Salah satu cara untuk mengatasi kurangnya ketrampilan menggosok gigi tersebut dengan cara memberikan pelatihan menggosok gigi dengan metode story telling.

Berdasarkan penjelasan diatas, kurangnya ketrampilan siswa dalam menggosok gigi pada anak usia prasekolah dikarenakan adanya pengaruh pada tingkat pendidikan orang tua dimana sebagian besar pendidikan orang tua adalah pendidikan menengah yaitu ayah 39 orang (55,7\%) dan ibu 42 orang $(60,0 \%)$. Menurut Sulistyaningsih (2015), makin rendah tingkat pendidikan orang tua akan berpengaruh pada perkembangan anak sehingga orang tua kurang memberikan stimulasi kepada anak yang menyebabkan stimulasi pada anak menjadi kurang baik. Disamping itu juga ada faktor yang membuktikan bahwa anak kurang dalam ketrampilan menggosok gigi karena masih terdapat sebagian besar anak pernah mengalami karies gigi yaitu 30 orang $(51,4 \%)$, hal ini dikarenakan kurangnya menjaga kebersihan gigi dan mulut dan cara menggosok gigi yang salah. Hal ini dibuktikan dengan hasil wawancara pada survey awal hampir setengah dari responden tidak rutin menggosok gigi.

Disamping faktor diatas, hasil penelitian menunjukkan bahwa setengah dari pekerjan ayah adalah swasta yaitu 35 orang (50\%) dan hampir setengah dari pekerjaan ibu adalah swasta yaitu 26 orang (37,1\%). Tussadiah (2014) mengatakan bahwa terdapat pengaruh pekerjaan orang tua terhadap perubahan perilaku dan motivasi belajar pada anak untuk meningkatkan ketrampilan. Pengaruh pekerjaan orang tua ini terjadi karena kesibukan orang tua untuk memenuhi kebutuhan hidup sehingga anak kurang mendapatkan perhatian yang penuh dari orang tua. 


\section{Ketrampilan menggosok gigi sesudah pelatihan storytelling}

Tabel 2 Distribusi frekuensi ketrampilan menggosok gigi sesudah pelatihan

\begin{tabular}{cccc}
\multicolumn{4}{c}{ storytelling } \\
\hline No. & Ketrampilan menggosok gigi & f & $\mathbf{( \% )}$ \\
\hline 1. & Baik & 43 & 61,4 \\
2. & Cukup & 27 & 38,6 \\
3. & Kurang & - & 0 \\
\hline Total & & $\mathbf{7 0}$ & $\mathbf{1 0 0}$ \\
\hline
\end{tabular}

Berdasarkan hasil observasi ketrampilan menggosok gigi sesudah dilakukan storytelling pada tabel 2, dapat disimpulkan bahwa sebagian besar ketrampilan menggosok gigi pada responden adalah baik sebanyak 43 responden $(61,4 \%)$. Adapun yang menyebabkan ketrampilan siswa menjadi baik karena adanya peningkatan perilaku anak prasekolah terhadap apa yang disampaikan melalui pelatihan menggosok gigi dengan metode story telling. Menurut Tatenge (2013) penggunaan metode story telling dapat meningkatkan pengetahuan dan ketrampilan anak prasekolah, hal ini dibuktikan bahwa sebagian besar ketrampilan menggosok gigi sesudah diberikan pelatihan menggosok gigi dengan metode story telling, ketrampilan anak meningkat menjadi lebih baik.

Ketrampilan siswa dalam menggosok gigi pada anak usia prasekolah menjadi baik dikarenakan adanya pengaruh pada usia anak dimana sebagian besar usia anak adalah 6-7 tahun sebanyak 36 orang (51,4\%). Menurut Havigusrt (1961) dalam Enung Sinta Nuriah (2015) anak usia 6-7 tahun sudah memiliki daya ingat yang baik dan sudah bisa mengerti tentang sebuah konsep, dan dalam perkembangannya sudah bisa melakukan pembelajaran tentang ketrampilan motorik maupun fisik sehingga anak prasekolah lebih cepat merubah perilaku, dari perilaku yang kurang menjadi perilaku yang lebih baik.

Disamping penjelasan diatas, ketrampilan siswa dalam menggosok gigi menjadi baik dipengaruhi oleh jenis kelamin, dimana pada hasil penelitian didapatkan bahwa hampir setengahnya berjenis kelamin laki-laki yaitu 37 responden (52,9\%). Menurut Martinovic (2016), mengatakan bahwa anak laki-laki cenderung lebih aktif dibandingkan dengan anak perempuan dalam berinteraksi sehingga antara anak perempuan dan anak laki-laki memiliki perbedaan pola interaksi sehingga mempengaruhi pula dengan tingkat ketrampilan anak. 


\section{Pengaruh pelatihan menggosok gigi dengan metode story telling terhadap ketrampilan menggosok gigi pada anak usia prasekolah}

Tabel 3 Hasil observasi ketrampilan menggosok gigi pada anak usia prasekolah

\begin{tabular}{|c|c|c|c|c|c|}
\hline \multirow[t]{2}{*}{ No } & \multirow[t]{2}{*}{ Kategori } & \multicolumn{2}{|c|}{ Ketrampilan Sebelum } & \multicolumn{2}{|c|}{ Ketrampilan Sesudah } \\
\hline & & $f$ & $\%$ & $f$ & $\%$ \\
\hline 1 & Baik & 14 & $20 \%$ & 43 & $61,4 \%$ \\
\hline 2 & Cukup & 24 & $34,3 \%$ & 27 & $38,6 \%$ \\
\hline 3 & Kurang & 32 & $45,7 \%$ & 0 & 0 \\
\hline \multirow{2}{*}{\multicolumn{3}{|c|}{$\begin{array}{l}\text { Total } \\
\qquad a=0,005\end{array}$}} & $100 \%$ & 70 & $100 \%$ \\
\hline & & & & \multicolumn{2}{|c|}{ pvalue $=0,000$} \\
\hline
\end{tabular}

Berdasarkan hasil observasi ketrampilan menggosok gigi sebelum dan sesudah dilakukan storytelling pada tabel 3, dapat disimpulkan bahwa sebagian besar ketrampilan menggosok gigi sebelum diberikan pelatihan adalah kurang, yaitu sebanyak 32 responden (45,7\%). Sedangkan ketrampilan menggosok gigi sesudah diberikan pelatihan adalah baik, yaitu sebanyak 43 responden $(61,4 \%)$. Kemudian setelah dilakukan uji hipotesis dengan menggunakan uji Wilcoxon didapat pvalue = 0,000 , karena nilai 0.000 lebih kecil dari $a=<0.05$, maka dapat disimpulkan bahwa Ho ditolak dan H1 diterima. Sehingga ada pengaruh pelatihan menggosok gigi dengan metode storytelling terhadap ketrampilan menggosok gigi pada anak usia prasekolah.

Adanya perubahan ketrampilan menggosok gigi tersebut dikarenakan terdapat perubahan bentuk perilaku responden sebelum dan sesudah pelatihan menggosok gigi diberikan, dimana sebelum diberikan pelatihan menggosok gigi hampir setengahnya ketrampilan responden kurang yaitu sebanyak 32 orang $(45,7 \%)$ sedangkan sesudah diberikan pelatihan menggosok gigi sebagian besar ketrampilan responden baik yaitu sebanyak 43 orang $(61,4 \%)$.

Perubahan ketrampilan responden tersebut karena anak usia prasekolah yang mendapatkan pelatihan cara menggosok gigi secara langsung akan lebih tertarik dan memiliki rasa ingin melakukan langkah-langkah yang diajarkan kepada mereka (Sudarty, 2015). Sedangkan adanya perubahan perilaku pada responden dari ketrampilan menggosok gigi yang kurang menjadi baik, karena memberikan pelatihan kepada anak usia prasekolah dengan menggunakan metode story telling dapat meningkatkan perilaku anak prasekolah (Tatenge, 2013). Dengan diberikannya pelatihan menggosok gigi dengan metode story telling maka berdampak positif bagi anak..

\section{KESIMPULAN DAN SARAN}

Berdasarkan uraian diatas dan hasil penelitian menunjukkan adanya pengaruh pelatihan menggosok gigi dengan metode storytelling terhadap ketrampilan 
menggosok gigi pada anak usia prasekolah. Agar penelitian tentang ketrampilan menggosok gigi pada anak usia prasekolah menjadi lebih komprehensif, dapat dimasukkan variabel penelitian lain yang belum tercakup dalam penelitian ini yaitu memberikan pelatihan kepada anak usia prasekolah dengan metode bercerita audiovisualmaupun dengan metode story telling yang lainnya.

\section{UCAPAN TERIMA KASIH}

Penulis mengucapkan terimakasih kepada Program Studi Ilmu Keperawatan Fakultas Ilmu Kesehatan Unversitas Kadiri serta para pembiming dan penguji yang telah memberikan bimbingan demi terselesaikannya karta tulis ini serta tak lupa kami ucapkan kepada Pemerintah Kabupaten Lamandau yang telah memberikan dukungan financial terhadap penelitian ini.

\section{DAFTAR PUSTAKA}

Anugraheni, I. 2017. Hypnoparenting Terhadap Temper Tantrum Pada Anak Prasekolah Di TK Islam TerpaduBinaInsaniKecamatanMojoroto Kota Kediri. Jurnal Keperawatan Vol 5 no.1. Maret 2017.

Badko. 2011. Tehnik Bercerita Untuk Anak Usia Dini, Kak Bimo Master Dongeng Indonesia. Badko TKA-TPA Mergangsan. [Serial online]

Delimasa, K. 2012. Media Boneka Tangan Dapat Meningkatkan Keterampilan Becerita. [Serial Online]

Depkes RI.2010. Kesehatan Gigi dan Mulut. Jakarta: Ditjen Pelayanan Publik.

Dewi. 2014. Efektivitas Menyikat Gigi Metode Horizontal, Vertikal dan Roll Terhadap Penurunan Plak Pada Anak Usia 9-11 Tahun. Jurnal Kedokteran Gigi.

Dinas Kesehatan Provinsi Kalimantan Tengah. 2015. Profil Kesehatan Provinsi Kalimantan Tengah Tahun 2015. Palangka Raya: Dinkes Provinsi Kalimantan Tengah

Dinas Kesehatan Provinsi Kalimantan Tengah. 2012. Profil Kesehatan Provinsi Kalimantan Tengah Tahun 2012. Palangka Raya: Dinkes Provinsi Kalimantan Tengah

Dinas Kesehatan Kabupaten Lamandau. 2017. Data Laporan LB-1 Tahun 2016.Nanga Bulik: Dinkes Lamandau

Dinas Pendidikan dan Kebudayaan Kabupaten Lamandau. 2016.Data Paud di Kabupaten Lamandau Tahun 2016. Nanga Bulik:Bid.Paud Dinas P dan K Lamandau.

Erwana. 2012. Seputar Kesehatan Gigi dan Mulut. Jakarta: Rapha Publishing. 
Jurnal Kesehatan Mahasiswa UNIK. Vol. 2, No. 1, Oktober 2020

P-ISSN: 2714-5409, E-ISSN: 2686-5300

Fitriani, S. 2011. Promosi Kesehatan. Yogyakarta: Graha Ilmu

Hasanah, S. 2013. Pengaruh Metode Bercerita Terhadap Karakter Anak Usia 5 - 6 Tahun Di TK FKIP Unri Pekanbaru.[Serial Online]

Iswandari. Winda. 2015. Gambaran Pengetahuan Anak Usia 7-12 tahun tentang Oral Hygiene Berdasarkan Karakteristik. Bandung: Universitas Pendidikan Indonesia

Karen, M \& Claudio. 2008. Pathway to Competence: Adversity the roles of Parenting Quality and Social Support. The Juornal of Psychology, 142 (4), 427-443. Helderf Publication.

Departemen Kesehatan RI.2013. Riset Kesehatan Dasar. Jakarta: Badan Penelitian dan Pengembangan Kesehatan

Departemen Kesehatan RI. 2014. Situasi Kesehatan Gigi dan Mulut. Jakarta: Pusat Data dan Informasi Kemenkes RI

Kestha. 2013. Using Story Telling in Teaching English in Oalestinian Schools: Perception and Difficulties. Education Journal. [Serial online]

Listiani, Agustina. Pelayanan Asuhan Gigi Masyarakat. [Serial Online].

Mutmainah, Basri. 2015. Proposal Karies Gigi.[Serial Online]

Notoatmodjo, S. 2007. Promosi Kesehatan dan Ilmu Perilaku. Jakarta: PT. Rineka Cipta

Notoatmodjo, S. 2010. Promosi Kesehatan dan Ilmu Perilaku. Jakarta: PT. Rineka Cipta

Nursalam. 2013. Konsep dan Penerapan Metodologi Penelitian Ilmu Keperawatan (Pedoman Skripsi, Tesis, Instrumen Penelitian Keperawatan). Jakarta: Salemba Medika

Papilia. D.E. 2008. Human Development (Psikologi Perkembangan). Alih Bahasa : A.K. Anwar. Jakarta: Kencana

Pintauli, S. dan Harmada. 2008. Menuju Gigi dan Mulut Sehat, Pencegahan dan Pemeliharaan. USU Press, Medan

Potter \& Perry. 2005. Buku Ajar Fundamental Keperawatan. Terjemahan oleh Yasmin Asih. Jakarta: EGC.

Puskesmas Bulik, 2015. Laporan LB-1 Tahun 2015. Nanga Bulik: Puskesmas Bulik

Puskesmas Bulik, 2016. Laporan LB-1 Tahun 2016. Nanga Bulik: Puskesmas Bulik 
Jurnal Kesehatan Mahasiswa UNIK. Vol. 2, No. 1, Oktober 2020

P-ISSN: 2714-5409, E-ISSN: 2686-5300

Pratiwi, Dian. 2016. Pengaruh Metode Storytelling Terhadap Perilaku Menggosok Gigi di TK Dharma Wanita IV Banjar Sengon. Jember: Universitas Jember

Rahmadhan, Ardyan. G. 2010. Serba Serbi Kesehatan Gigi dan Mulut. Jakarta

Riyanto, A. 2013. Statistik Deskriptif Untuk Kesehatan. Yogyakarta: Nuha Medika

Santrock, J. 2007. Psikologi Pendidikan (terjemahan). Jakarta: Kencana Prenada Media Group

Sariningsih. 2012. Merawat Gigi Sejak Dini. Jakarta: Gramedia.

Sehat Fresh. 2015. Lima Indikator Kesehatan Rongga Mulut. Sehat Fresh.com

Silver, D. 2011. Influencing Health Brhavior: Songs and Storytelling: Bringing Health Messages to Life in Uganda. [Serial Online]

Sudarty. 2015. Pengaruh Pelatihan Gosok Gigi Terhadap Praktek Menjaga Kebersihan Gigi Pada Anak Usia Prasekolah di TK Pertiwi 55 Kasihan Bantul. Naskah Publikasi.

Sugiyono. 2010. Metode Penelitian Kuantitatif Kualitatif dan R\&D. Bandung: Alfabeta

Susan,U.N. dkk. 2016. Gambaran Pengetahuan dan Sikap Menyikat Gigi pada SiswaSiswi Dalam Mencegah Karies Gigi.

Tatenge. 2013. Meningkatkan Perilaku Hidup Bersih dan Sehat Nelalui Metode Demonstrasi di Kelompok A TK Putra Bangsa Berdikari Kecamatan Palolo. Journal Bungapati. [Serial online]

Wong, D.L. 2009. Buku Ajar Keperawatan Pediatrik. Jakarta: EGC

World Health Organization. 2015. Future Use Material for Dental Restoration, World Health Organization, Switzerland, [Serial online]

Yunalia, E. M. 2016. Pengaruh Terapi Terapeutik Terhadap Kemampuan Orang Tua Tunggal Dalam Memberikan Stimulasi Perkembangan Anak Usia Prasekolah. Jurnal Care.Program Studi Ilmu Keperawatan. Fakultas Ilmu Keperawatan Universitas Kadiri.Tahun 2016. 